\title{
Endoscopic drainage and cystoduodedonstomy in a child with pancreatic pseudocyst
}

\author{
Ufuk Ateş, M.D.,, ${ }^{1}$ Gönül Küçük, M.D., ${ }^{1}$ Kubilay Çınar, M.D., ${ }^{2}$ Berktuğ Bahadır, M.D., ${ }^{3}$ \\ Mehmet Bektaş, M.D., ${ }^{2}$ Gülnur Göllü, M.D., ${ }^{1}$ Meltem Bingöl Koloğlu, M.D. ${ }^{1}$
}

\author{
${ }^{1}$ Department of Pediatric Surgery, Ankara University Faculty of Medicine, Ankara-Turkey \\ ${ }^{2}$ Department of Gastroenterology, Ankara University Faculty of Medicine, Ankara-Turkey \\ ${ }^{3}$ Department of Pediatric Surgery, Mersin University Faculty of Medicine, Mersin-Turkey
}

\begin{abstract}
An II-year-old morbidly obese boy was diagnosed with pancreatic pseudocyst. Following fine needle aspiration, the cyst recurred in I-month follow-up. Therefore, endoscopic drainage and cystoduodenostomy was performed following endosonography. Control ultrasonography (USG) revealed a completely shrunken cyst. During the 3 years of follow-up, the patient was asymptomatic with no evidence of cyst on computerized tomography scans. Endoscopic drainage and cystoduodenostomy is a minimally invasive, effective, and safe approach in the management of pancreatic pseudocysts in children.
\end{abstract}

Keywords: Children; drainage; endosonography; pancreas.

\section{INTRODUCTION}

Pancreatic pseudocysts (PP) are rare, but potentially troublesome problem in the pediatric population. They usually result from pancreatic insult with ductal disruption and majorities are secondary to trauma. ${ }^{[1]}$ When attempts at conservative medical management fail, drainage of the pseudocyst is warranted. Surgical drainage procedures have long been the gold standard for treating persistent, symptomatic pseudocysts. ${ }^{[2]}$ Most recently, laparoscopic and endoscopic techniques have been applied to manage this problem. Endoscopic procedures have mostly been utilized in adult population and the pediatric literature on these techniques is limited. In this case report, we aimed to share our experience in endoscopic drainage and cystoduodenostomy in a child with PP.

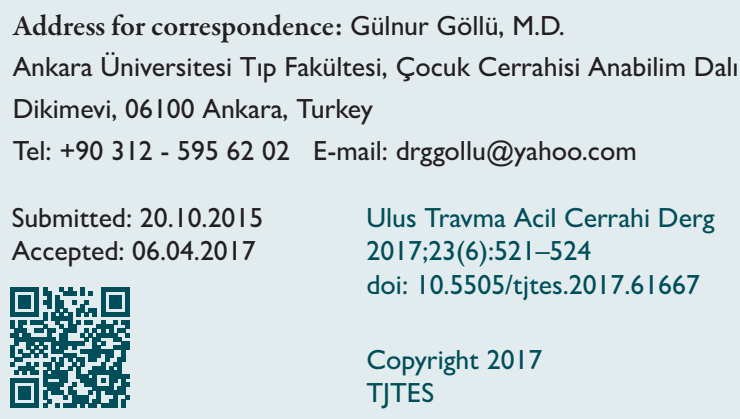

\section{CASE REPORT}

An II-year-old boy presented with abdominal pain and vomiting episodes for 2 months. He had a history of injury during a motor vehicle accident 3 months ago. He was treated for humerus fracture and evaluated for abdominal pain. Abdominal ultrasonography done on the first admission was reported to be normal. However, abdominal computerized tomography (CT) scans done on the second admission demonstrated a 7 $\times 6-\mathrm{cm}$ cyst located in the head of pancreas, causing duodenal compression (Fig. Ia).

First, ultrasonography-guided percutaneous aspiration of the cyst was performed, which revealed $50 \mathrm{ml}$ of turbid fluid with increased amylase level. The cyst shrank to $2 \mathrm{~cm}$ after aspiration, but enlarged to $8 \mathrm{~cm}$ in 1 month of follow-up. Therefore, endoscopic drainage and cystoduodenostomy was planned. Endosonography done before the procedure showed that there was no vascular structure between the cyst wall and duodenum and there was no epithelial lining or muscular structure in the cyst wall (Fig. Ib). Endoscopy was performed with a side-viewing duodenoscope and revealed extrinsic compression of the duodenal bulb (Fig. 2a). A needle-knife papillotome was then used to incise the duodenal and pseudocyst walls using electrocautery. The needle was withdrawn and the catheter advanced into the cyst to serve as a conduit for guidewire placement (Fig. 2b). The guidewire was advanced into the pseudocyst and was seen coiling in the 

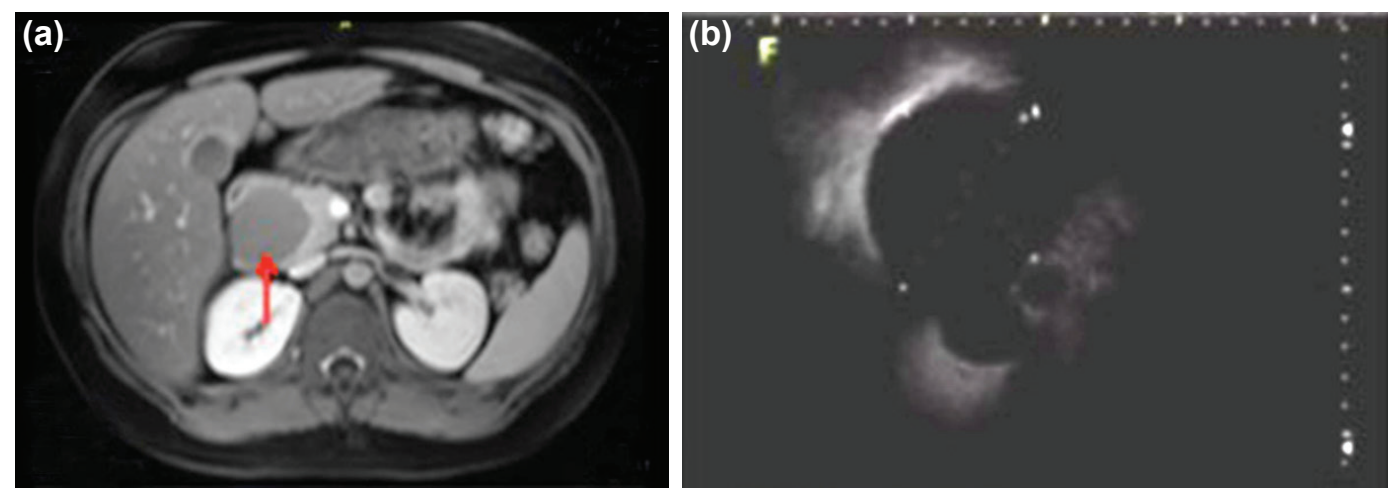

Figure 1. Computerized tomography scan showing a pancreatic pseudocyst at the head of pancreas (arrow) (a) and endosonography view showing the pancreatic pseudocyst without an epithelial lining or muscle wall (b).

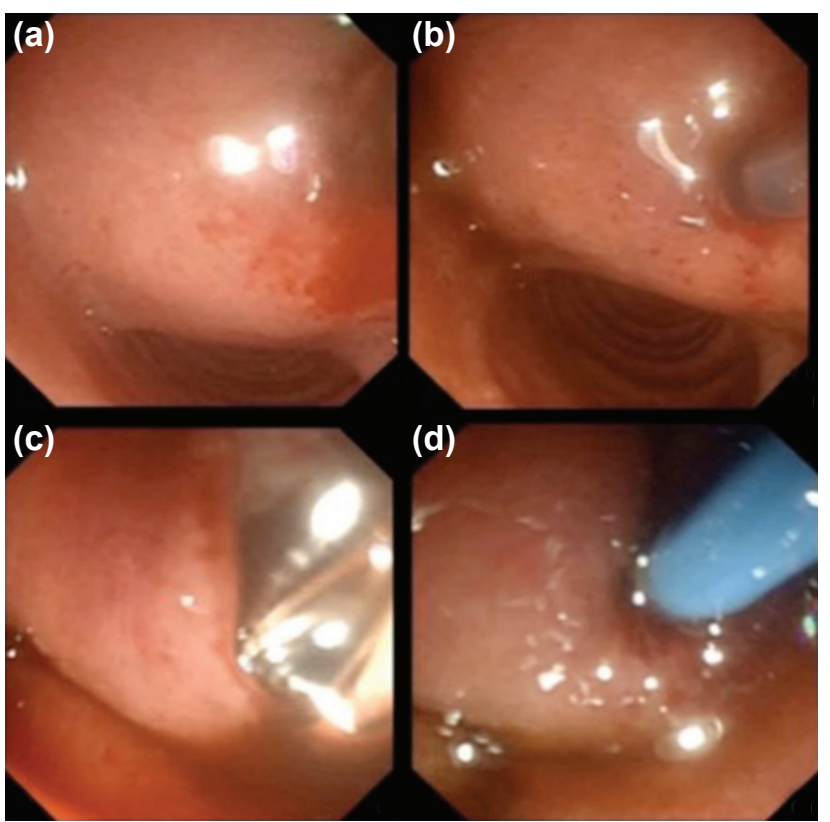

Figure 2. Endoscopic view showing extrinsic compression of the duodenal bulb by the cyst (a), needle-knife papillotome incising duodenal and pseudocyst walls (b), balloon dilatation of cystoduodenostomy opening (c), and double-pigtail stent in the cystoduodenostomy (d).

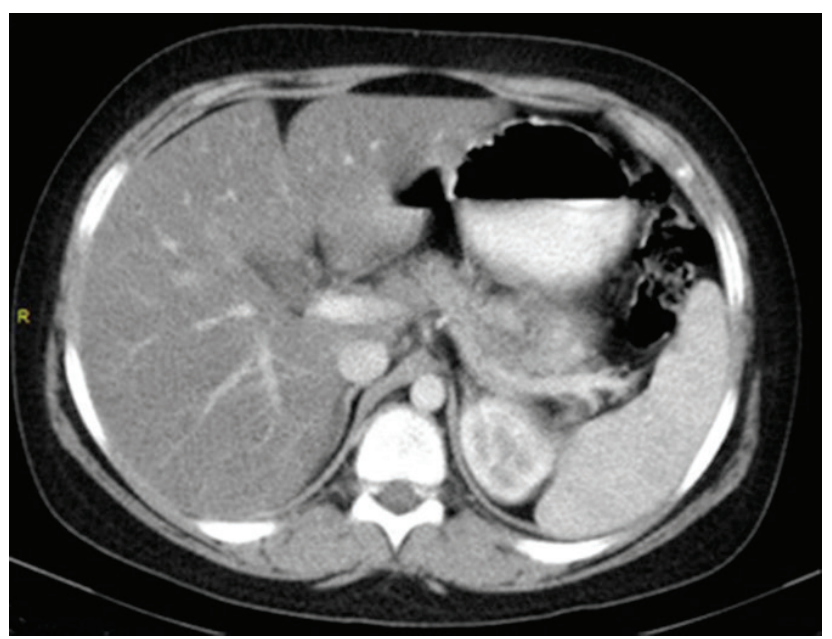

Figure 3. Follow-up: No evidence of cyst on CT scans. large cavity. Cystoduodenostomy opening was easily dilated using an 8-10-mm diameter pneumatic balloon (Fig. 2c). Two double-pigtail plastic stents were placed across the cystoduodenostomy window to maintain patency and allow complete resolution of the pseudocyst (Fig. 2d). Postoperative course was uneventful. The patient tolerated oral feeding on postoperative first day and was discharged on postoperative second day. The stents were spontaneously evacuated 12 months after the procedure. During the 3 years of follow-up, the patient remained asymptomatic and is currently doing well with no evidence of cyst on CT scans (Fig. 3).

\section{DISCUSSION}

Pancreatic pseudocyst (PP) is a rare but potentially troublesome problem in the pediatric population. They usually result from pancreatic insult with ductal disruption and majorities are secondary to trauma. ${ }^{[1]}$ When attempts at conservative medical management fail, draining the pseudocyst is warranted. Surgical drainage procedures have long been the gold standard for treating persistent, symptomatic pseudocysts. ${ }^{[2]}$ Most recently, laparoscopic and endoscopic techniques have been applied to manage this problem. Endoscopic procedures have mostly been used in adult population, and the pediatric literature on these techniques is limited. In this case report, we aimed to share our experience in endoscopic drainage and cystoduodenostomy in a child with PP.

Pancreatic pseudocyst is a cystic cavity bound to the pancreas without an epithelial lining, which occurs following an injury to the pancreatic parenchyma or pancreatic duct. ${ }^{\left[{ }^{[]}\right.}$It is also a well-recognized complication of acute pancreatitis, chronic pancreatitis, and pancreatic trauma. ${ }^{[3]}$ PP is uncommon in children and majority of these are secondary to trauma. ${ }^{[2]}$ The cyst must be drained when it causes complications such as pain, compression, hemorrhage, infection or fails to spontaneously resolve. The management depends on the size, localization, presence, or absence of infection and age of the pseudocyst. ${ }^{[2]}$ Usually, the size is a good predictor of spontaneous resolution: cysts smaller than $4 \mathrm{~cm}$ resolve in $90 \%$ of 
cases, whereas cysts larger than $6 \mathrm{~cm}$ have only a $20 \%$ chance of resolving. ${ }^{[2]}$

The management of PP has changed with the times, mainly during the past decade. Surgical drainage has been the traditional approach and gold standard of treatment because of the superior results. ${ }^{[2]}$ The type of surgical procedure, that is, pseudocystogastrostomy or pseudocystojejunostomy, is largely dependent on the site of PP. These procedures can also be laparoscopically performed. With the advent of USG and CT techniques, percutaneous drainage has been proved to be more feasible and attractive in nonoperative management of PP. According to Warner et al., ${ }^{[4]}$ most childhood pseudocysts are acute and thin-walled and share no connection with underlying pancreatic duct obstruction or associated disease. As discussed by Warner et al., in the adult literature, external drainage is recommended only for patients with immature friable pseudocysts or infected and ruptured cysts or for patients who are very ill. However, external drainage is one of the treatment of choice for pseudocysts in children. The procedure can be done quickly and effectively, and it does not preclude other surgical procedures if further measures become necessary. In adults, alcoholic pancreatitis is the principal cause of pseudocysts; however, traumas can also a cause in children. External drainage has not resulted in dismal failure rates in the pediatric age group. The reason for this may be that virtually all pseudocysts in children are traumatic. The underlying pancreatic duct and parenchyma are usually normal. ${ }^{[5]}$ Although there is a high incidence of pancreaticocutaneous fistula formation after external drainage in adults, this risk is lower in children. ${ }^{[4]}$ As discussed by Burnweit et al., ${ }^{[5]}$ when PP develops and persists in the post-traumatic setting, percutaneous drainage can be tried in nonoperative management of pancreatic pseudocyst in children. However, its higher recurrence rate is a drawback, and the application largely depends on the expertise of the institutions in pediatric population. ${ }^{[6]}$ We also tried percutaneous drainage initially in our case, but there was recurrence; therefore, endoscopic drainage and cystoduodenostomy were performed.

Since 1985, there have been reports of endoscopic drainage of PP by placing stents between pseudocyst and gastrointestinal tract in adults. However, the experience in pediatric population is limited. The available methods of endoscopic drainage are cystoenterostomy or transpapillary drainage. ${ }^{[3]}$ Transpapillary drainage may be specifically needed for cases associated with pancreatic duct anomalies. For a safe and successful endoscopic drainage, a visible bulging of the gastric or duodenal wall at the site of pseudocyst and a cyst wall thickness less than $1 \mathrm{~cm}$ are warranted. ${ }^{[3,6]}$ The contraindications of endoscopic drainage are hemorrhage, infection, and a distance greater than $\mathrm{I} \mathrm{cm}$ from the gut lumen to the inner cyst wall. [2] The thickness of the wall is important because endoscopic drainage becomes technically more difficult in cysts with thicker wall and carries an increased risk of complications and failure. ${ }^{[6]}$ Complications include bleeding, intestinal perfora- tion, infection, technical failure to drain the cyst, stent occlusion, stent leakage, stent migration, and recurrence of PP. ${ }^{[3]}$

To assess the wall thickness, to identify major vascular structures, and to find the closest access to fluid cavity, endoscopic ultrasound-guided drainage of PP has been utilized in many centers recently. ${ }^{[7-10]}$ Another advantage of endosonography is that it allows differentiating pseudocyst from duplication cyst by showing that there is no epithelial lining or muscular structure in the cyst wall. In our case, endosonography showed no muscle lining in the cyst wall, and there were no gross vascular structures between duodenal wall and PP that could compromise the success of the procedure.

It is recommended that all cystenterostomies should be stented to avoid recurrence and spontaneous stent migration can be minimized by using double-pigtail stents, as done in our case. ${ }^{[7]}$ The duration of leaving the stent in situ has not been well-defined yet. Most investigators report leaving the stent in place for 2-4 months or until ultrasonography confirms pseudocyst resolution before endoscopic removal. In some adult patients, the stent has been left in place for 2 years without complication, and sometimes the stent has spontaneously passed. ${ }^{[6,7]}$ We were planning to remove the stents 12 months after the procedure; however, they were spontaneously evacuated.

Depending on our experience, the endoscopic drainage of PP and cystoduodenostomy is a minimally invasive, effective, and safe approach, and it is applicable to the pediatric population. In experienced hands, it is a simple and minimal invasive alternative to surgery or percutaneous drainage.

Conflict of interest: None declared.

\section{REFERENCES}

1. Teh SH, Pham TH, Lee A, Stavlo PL, Hanna AM, Moir C. Pancreatic pseudocyst in children: the impact of management strategies on outcome. J Pediatr Surg 2006;41:1889-93. [CrossRef]

2. Patty I, Kalaoui M, Al-Shamali M, Al-Hassan F, Al-Naqeeb B. Endoscopic drainage for pancreatic pseudocyst in children. J Pediatr Surg 2001;36:503-5. [CrossRef]

3. Al-Shanafey S, Shun A, Williams S. Endoscopic drainage of pancreatic pseudocysts in children. J Pediatr Surg 2004;39:1062-5. [CrossRef]

4. Warner RL Jr, Othersen HB Jr, Smith CD. Traumatic pancreatitis and pseudocyst in children: current management. J Trauma 1989;29:597601. [CrossRef]

5. Burnweit C, Wesson D, Stringer D, Filler R. Percutaneous drainage of traumatic pancreatic pseudocysts in children. J Trauma 1990;30:1273-7.

6. Kimble RM, Cohen R, Williams S. Successful endoscopic drainage of a posttraumatic pancreatic pseudocyst in a child. J Pediatr Surg 1999;34:1518-20. [CrossRef]

7. Breckon V, Thomson SR, Hadley GP. Internal drainage of pancreatic pseudocysts in children using an endoscopically-placed stent. Pediatr Surg Int 2001;17:621-3. [CrossRef]

8. Sadik R, Kalaitzakis E, Thune A, Hansen J, Jönson C. EUS-guided drainage is more successful in pancreatic pseudocysts compared with $\mathrm{ab}$ scesses. World J Gastroenterol 2011;17:499-505. [CrossRef] 
9. Kalaitzakis E, Panos M, Sadik R, Aabakken L, Koumi A, Meenan J. Clinicians' attitudes towards endoscopic ultrasound: a survey of four European countries. Scand J Gastroenterol 2009;44:100-7. [CrossRef]
10. Seewald S, Ang TL, Teng KC, Soehendra N. EUS-guided drainage of pancreatic pseudocysts, abscesses and infected necrosis. Dig Endosc 2009;21 Suppl 1:S61-5. [CrossRef]

\section{OLGU SUNUMU - ÖZET}

\section{Pankreatik psödokistli bir çocukta endoskopik drenaj ve kistoduodenostomi}

Dr. Ufuk Ateş, ${ }^{1}$ Dr. Gönül Küçük, ${ }^{1}$ Dr. Kubilay Çınar, ${ }^{2}$ Dr. Berktuğ Bahadır, ${ }^{3}$ Dr. Mehmet Bektaş, ${ }^{2}$ Dr. Gülnur Göllü, ${ }^{1}$ Dr. Meltem Bingöl Koloğlư ${ }^{1}$

${ }^{1}$ Ankara Üniversitesi Tıp Fakültesi, Çocuk Cerrahisi Anabilim Dalı, Ankara

${ }^{2}$ Ankara Üniversitesi Tıp Fakültesi, Gastroenteroloji Anabilim Dalı, Ankara

${ }^{3}$ Mersin Üniversitesi Tıp Fakültesi, Çocuk Cerrahisi Anabilim Dalı, Mersin

Pankreas psödokisti tanısı alan II yaşındaki erkek çocuğun ince iğne aspirasyon biyopsisi sonrasında takipte birinci ayda tekrarladığı izlendi. Endosonografi yardımlı endoskopik drenaj ve üç yıllık takipte herhangi bir problem olmayan hastanın kontrol bilgisayarlı tomografsinde kist izlenmedi. Çocuklarda pankreatik psödokist yönetiminde endoskopik drenaj ve kistoduodenostomi minimal invaziv, güvenli ve etkin bir yöntemdir. Anahtar sözcükler: Çocuk; drenaj; endosonografi; pankreas.

Ulus Travma Acil Cerrahi Derg 2017;23(6):521-524 doi: 10.5505/tjtes.2017.61667 